\title{
PENGARUH MEDIA PEMBELAJARAN BERBASIS AUGMENTED REALITY (AR) TERHADAP HASIL BELAHAR BIOLOGI SISWA SMA
}

\author{
Rismawati Kamaruddin ${ }^{1}$ \\ Rahmatia Thahir ${ }^{2 *}$ \\ Prodi Pendidikan Biologi, FKIP, Universitas Muhammadiyah Makassar, Indonesia \\ rismawatikamaruddin7@gmail.com ${ }^{1)}$ \\ rahmatiah.thahir@unismuh.ac.id ${ }^{2 *}$
}

\begin{abstract}
Abstrak
Penelitian eksperimen ini bertujuan untuk mengetahui pengaruh media pembelajaran berbasis Augmented Reality (AR) terhadap hasil belajar siswa pada materi virus kelas X SMA Negeri 1 Gowa. Penelitian ini terdiri dari dua variabel yaitu media pembelajaran berbasis Augmented Reality (AR) sebagai variabel bebas dan hasil belajar siswa sebagai variabel terikat dengan menggunakan desain penelitian Posttest-Only Control Group Design. Populasi dalam penelitian ini adalah seluruh siswa kelas $\mathrm{X}$ SMA Negeri 1 Gowa yang terdiri atas 7 kelas dengan jumlah siswa 252 orang. Sampel dalam penelitian ini adalah kelas X MIA 3 sebagai kelas eksperimen dengan jumlah siswa sebanyak 36 orang dan kelas X MIA 4 sebagai kelas control dengan julah siswa sebanyak 36 orang. Penentuan kelas kedua sampel ini terpilih melalui Teknik Simple Random Sampling. Data yang diperoleh dianalisis dengan statistik deskriptif dan stratistik inferensial. Hasil analisis statistik deskriptif memperlihatkan bahwa kelas yang diajar dengan menggunakan media pembelajaran yang berbasis Augmented Reality (AR) diperoleh rata-rata hasil belajar sebesar 80 , sedangkan kelas yang diajar dengan media biasa digunakan guru bidang studi diperoleh rata-rata hasil belajar sebesar 73. Ketuntasan belajar siswa kelas eksperimen adalah $86,1 \%$ sedangkan ketuntasan belajar siswa kelas control adalah 47,2\%. Hasil pengujian sitatistik inferensial untuk analisis hipotesis dengan uji Independent Samples T-Test diperoleh nilai signifikansi $\mathrm{p}=0,001<\alpha=0,05$. Hail ini menunjukkan bahwa $\mathrm{H}_{0}$ ditolak dan $\mathrm{H}_{1}$ diterima. Dengan demikian media pembelajaran berbasis Augmented Reality (AR) berpengaruh terhadap hasil belajar siswa pada materi virus kelas X SMA Negeri 1 Gowa.
\end{abstract}

Kata Kunci: Augmented Reality (AR), Hasil Belajar.

Published by:

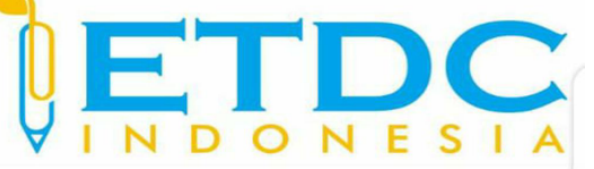

Copyright (C) 2021 The Author (s)

This article is licensed under CC BY 4.0 License (cc) $\mathrm{BY}$ 


\section{PENGARUH MEDIA PEMBELAJARAN BERBASIS AUGMENTED REALITY (AR) TERHADAP HASIL BELAJAR BIOLOGI SISWA SMA}

\section{Pendahuluan}

Pendidikan dibutuhkan manusia untuk berkembangan dan tidak terbelakang dalam segala hal. Pendidikan merupakan belajar sampai akhir hayat. Pendidikan dibutuhkan dimanapun dan kapan pun. Seperti yang terdapat dalam undang-undang tentang system Pendidikan Nasional No. 20 tahun 2003 bahwa pendidikan adalah usaha sadar dan terebcana untuk mewujudkan potensi dirinya untuk memiliki kekuatan spiritual keagamaan, pengendalian diri, kepribadian, kecerdasan, akhlak mulia, serta keterampilan yang diperlukan dirinya, masyarakat, bangsa dan negara.

Upaya untuk mengembangkan sumber daya manusia yang berkualitas merupakan arah dari keterlaksanaan pendidikan. Untuk membentuk manusia yang berkualitas memerlukan lingkungan yang mendukung untuk mengembangkan kemampuan secara optimal sehingga dapat mewujudkan potensi yang ada pada dirinya sesuai dengan kebutuhan pribadi maupun masyarakat. Salah satu sarana untuk mengembangan diri dan meningkatkan kulitas hidup adalah sekolah. Sekolah adalah tempat mengembangkan bakat dan minat yang dimiliki oleh setiap siswa. Sekolah juga tempat memperoleh banyak mata pelajaran yang diajarkan seorang guru kepada siswa. Salah satu mata pelajarannya adalah biologi.

Biologi merupakan salah satu bidang studi dalam ilmu pengetahuan alam yang mempelajari makhluk hidup dan sekitarnnya, Mempelajari biologi tidaklah sia-sia karena memiliki banyak manfaatnya dalam kehidupan sehari-hari. Biologi mempelajari struktr dari manusia, hewan dan tumbuhan serta struktur organisme terkecil seperti bakteri dan virus. Walaupun demikin masih banyak siswa kurang paham terhadap konsep biologi tertentu karena proses penyampaian pengetahuan tidak terlaksanakan dengan baik dan siswa belum mampu memaknai konsep secara fleksibel sehingga penguasaan konsep-konsep biologi rendah. Hal ini menyebabkan perolehan nilai akhir tidak berhasil mencapai nilai KKM yang ditetapkan.

Setelah melakukan observasi di SMA Negeri 1 Gowa kelas X diperoleh informasi bahwa ada beberapa siswa belum bisa memahami pembelajaran biologi materi virus dengan baik, sehingga mereka pasif pada saat proses pembelajaran berlangsung. Nilai rata-rata ulangan harian siswa jauh lebih rendah dibandingkan nilai KKM yang ingin dicapai yaitu 75. Siswa yang mencapai KKM sebesar 55\% hingga masih ada 45\% siswa yang belum mencapai KKM. Salah satu yang menyebabkan hal tersebut terjadi karena dalam proses pembelajran kurangnya 
penggunaan media pembelajaran. Sehingga siswa kurang bersemangat dalam belajar, hal ini pula mempengaruhi hasil belajar dari beberapa siswa.

Penggunaan media pembelajaran membantu proses pembelajaran menjadi efektif dan menarik, serta penyampaian pesan atau isi dari materi pelajaran sehingga menjadikan pembelajaran berkualitas dan meningkatkan hasil belajar siswa. Guru dapat memanfaatkan media sebagai alat bantu dalam pembelajaran. Media dapat berupa gambar, grafik, film, slide power point, serta pembelajaran dengan menggunakan IT yang membantu menyampaikan informasi secara visual dan verbal. Media pembelajaran diharapkan dapat memberikan pengalaman belajar yang sesuai dengan materi ajar, memotivasi siswa untuk belajar, meningkatkan daya tangkap dan perhatian siswa dalam belajar. Dengan perkembangan zaman yang begitu pesat penggunaan Augmented Reality (AR) yang dimanfaatkan sebagai media dan salah satu sumber belajar dalam proses pembelajaran bisa meningkatkan mutu dan kualitas Pendidikan Indonesia. Karena pendidikan membutuhkan adanya pemberuan atau melakukan inovasi dalam pembelajaran yang setiap saat dapat perubahan mengikuti trend zaman.

Media pembelajaran dengan berbasis pada Augmented Reality (AR) adalah media yang menggabungkan komponen dalam Augmented Reality yang bersifat teknologi berupa gambar, internet, video, dan sebagainya (Riyana, 2012). AR adalah salah satu ternologi interaktif yang mampu menyatukan sesuatu yang bersifat nyata dan virtual sehingga menghasilkan objek tiga dimensi (3D) yang dapat dilihat di layer smartphone penggunanya. Cara kerja dari Augmented Reality dapat mendeteksi citra atau gambar yang disebut sebagai marker, menggunakan kamera pada handphone atau smartphone. Media pembelajaran berbasis Augmented Reality dalam penggunaannya diharapkan dapat memberikan bantuan pada saat seorang guru menyampaikan materi ajar sehingga lebih menarik. Media pembelajaran ini juga dapat menjadi salah satu alternatif media yang tepat karena dapat menyampaikan materi ajar dalam biologi yang dianggap sulit dipahami siswa disampaikan secara kontekstual, materi ajar diberikan tidak hanya secara teoritis saja tetapi juga menampilkan pengamatan gambar yang lengkap dengan keterangan bagian-bagiannya, serta gambar dengan tampilan menarik, animasi, video dan lainlain ditampilkan dengan aplikasi Augmented Reality. Sehingga dapat menjadikan siswa lebih kreatif, aktif, dan pemahaman siswa terhadap pelajaran lebih baik, hal tersebut dapat meningkatkan hasil belajar siswa.

Berdasarkan yang telah dilakukan oleh (Halidi et al., 2015), bahwa media pembelajaran berbasis Augmented Reality menjadi kesenangan tersendiri untuk siswa karena membantu siswa menjadi lebih aktif pada saat proses pembelajaran berlangsung, sehingga sangat disarankan guru menggunakan media ini untuk meningkatkan hasil belajar mereka. Selain itu, 
dengan media ini siswa dibantu untuk mengingat dan mengatur informasi materi ajar yang diterima. Berdasarkan hal tersebut maka peneliti merasa perlu untuk mengetahui apakah penggunaan media pembelajaran Augmented Reality memiliki dampak signifikan terhadap hasil belajar siswa.

Media berasal dari kata latin ( jamak: medium) yang berarti perantara atau pengantar (Riyana, 2012). Media pembelajaran adalah segala sesuatu yang dapat digunakan untuk menyampaikan pesan dan merangsang terjadinya proses pembelajaran pada siswa (Aqib, 2013). Makna dari media pembelajaran yang digunakan adalah sebagai alat bantu mengajar, alat peraga, dan media audio visual. Media pembelajaran menurut Asociation of Aducation and Communition Technology (AECT) bahwa media pembelajaran computer adalah perangkat lunak (software) yang berisi pesan atau informasi pembelajaran yang disajikan dengan menggunakan perangkat keras (hardware) computer. Dari beberapa definisi dapat disimpulkan bahwa media pembelajaran adalah segala sesuatu yang dapat menyampaikan pesan, merangsang pikiran, perasaan dan kemauan siswa sehingga dapat mendorong terjadinya proses belajar pada dirinya.

Media bertujuan untuk memberi kemudahan dalam berkomunikasi dan belajar. Salah satu media pembelajaran yang mudah digunakan dan sesuai dengan perkembangan zaman adalah Hp android. Pada era globalisasi saat ini, Hp android menjadi barang yang sangat dibutuhkan bahkan sudah mendari kebutuhan primer dalam kehidupan sehari-hari termasuk juga dalam kegiatan belajar mengajar guru dan siswa. Hp android adalah produk elektronik hasil perkembangan dan aplikasi sains dan teknologi yang dapat menerima perintah atau menyimpan data digital, memproses data, dan mengeluarkan hasil data yang diproses (output). Bermula pada tahun 1940an sebagai awal dari sejarah perkembangan elekronik yang terus mengalami perkembangan pesat sampai sekarang ini (Muslih, 2016). Media pembelajaran mempunyai dua unsur penting yaitu unsur peralatan atau perangkat keras (hardware) dan unsur pesan yang dibawanya (message/software). (Riyana, 2012) menyatakan bahwa perangkat lunak (software) adalah informasi atau bahan ajar itu sendiri yang akan disampaikan kepada siswa, sedangkan perangkat keras (hardwade) adalah peralatan yang digunakan untuk menyajikan pesan/ bahan ajar. Media secara umum mempunyai kegunaan yaitu untuk memperjelas pesan agar tidak verbalitas, mengatasi keterbatasan ruang, waktu, tenaga dan daya indra, menimbulkan gairah belajar, interaksi lebih langsung antara siswa dan sumber belajar, serta membantu siswa belajar mandiri sesuai dengan bakat, visual auditori, dan kinestetiknya.

Adanya media dalam pembelajaran sangat membantu siswa untuk memahami konsep dari materi yang dianggap sulit dijelaskan dengan menggunakan Bahasa verbal. Pemanfaatan 
media memang harus terencana dan sistematik sesuai dengan tujuan penbelajaran. Maka dari itu pemanfaatan media juga tergantung pada karakteristik media serta kemampuan guru dan siswa memahami cara menggunakan media itu. Dimana media pembelajaran dalam proses belajar dapat membangkitkan keinginan dan minat siswa, memberikan motivasi belajar, serta berpengaruh besar terhadap aktivitas dalam kegiatan belajar siswa (Aqib, 2013). Dalam teori Cone Experience, pengetahuan akan semakin abstrak apabila pesan hanya disampaikan melalui kata verbal. Sehingga siswa hanya paham akan sesuatu pengetahuan dalam bentuk kata, tanpa memahami makna dan mengerti apa yang terdapat dalam pengetahuan itu. Maka dari itu siswa harus memiliki pengalaman yang lebih nyata agar tidak menafsirkan terhadap pengetahuan yang diajarkan. Salah satu cara agar siswa memiliki pemahaman yang konkret adalah dengan menggunakan media pembelajaran dalam proses pembelajarannya (Aqib, 2013).

Sekarang ini pemanfaatan media cenderung pada media berbasis teknologi. Perkembangan teknologi Pendidikan berbarengan dengan perkembangan media dalam pembelajaran, sehingga menambah jenis-jenis dari media yang digunakan guru dalam proses pembelajaran (Mehram, 2017). Saat ini juga, terdapat salah satu jenis animasi yang sangat diminati oleh peminat teknologi dimana dalam penerapannya digabungkan antara dua dimensi yang berbeda. Hal ini membuat Pendidikan semakin penasaran dan tertarik untuk menggunakannya dalam kegiatan pembelajaran di kelas. Nama aplikasi yang dimaksud adalah Augmented reality (AR). AR merupakan media yang menggabungkan dunia nyata dan virtual yang bersifat interaktif dalam penerapannya.

Perkembangan Augmented Reality dilakukan secara besar-besaran, salah satunya pada bagian marker. Marker ini adalah sebuah penanda khusus yang memiliki pola tertentu sehingga saat kamera mendeteksi marker, objek 3D dapat ditampilkan. Marker yang pertama disebut marker based traking. Marker ini sudah cukup lama dikembangkan ssejak 1980-an, dan pada awal 1990-an mulai dikembangkan untuk penggunaan Augmented Reality. Kemudian markerless, perkembangan dari marker terbaru ini merupakan salah satu metode Augmented Reality yang tanpa menggunakan frame marker sebagai objek yang dideteksi. Adanya Markerless augmented reality maka pengguna marker sebagai tracking object yang selama ini menghabiskan ruang akan digantikan dengan gambar atau permukaan apapun yang berisi dengan tulisan, logo, atau gambar sebagai tracking object (objek yang dilacak) agar dapat langsung melibatkan objek yang dilacak sehingga terlihat hidup dan interaktif, juga tidak lagi mengurangi efisiensi ruang (Riyana, 2012).

Proses kerja Augmented Reality menggunakan Teknik visi komputer untuk mengkalkulasikan sudut pandang kamera nyata ke dalam marker yang nyata. Berikut adalah 
proses kerja AR 17 yaitu kamera menangkap video dari dunia nyata dan mengirimnya ke komputer, software di dalam komputer mencari melalui setiap frame video untuk setiap bentuk persegi, jika persegi ditemukan, perangkat lunak menggunakan beberapa Teknik matematika untuk menghitung posisi kamera terhadap persegi tersebut, setelah posisi kamera mengenal grafis, model computer akan diambil dari posisi yang sama, model akan muncul pada penanda persegi, dan hasil akhir ditampilkan Kembali di layer computer, sehingga akan terlihat objek 3D tambahan.

Augmented Reality memberikan keuntungan kepada guru dan siswa dalam pembelajaran. Keuntungan atau manfaat terhadap pembelajaran menggunakan Augmented Reality tersebut antara lain siswa menjadi lebih mudh dalam belajar, karena siswa lebih menyukai melakukan secara langsung atau praktek dibandingkan hanya memberikan teori. Ketika melakukan prose belajar, baik siswa maupun guru sangat terbantu dengan adanya internet untuk mencari sumber belajar. Proses belajar mengajar dengan menggunakan media Augmented Reality lebih menarik, misalnya dengan memuculkan gambar ataupu suara sehingga siswa lebih bersemangat untuk belajar. Apapun itu biasanya ada dampak positif dan negatif, tanpa terkecuali proses pembelajaran dengan menggunakan teknologi. Dampak negative dari pembelajaran menggunakan teknologi sebagai berikut; proses pembelajaran hanya bisa berlangsung hanya pada sekolah dengan peralatan yang lengkap, untuk sekolah-sekolah yang tidak lengkap peralatan teknologinya maka akan ketinggalan, dan siswa dari lulusan sekolah tersebut akan kesulitan jika masuk ke sekolah lanjutan di kota besar dengan peralatan teknologi yang sudah lengkap. Proses belajar mengajar, siswa tidak bersemangat dalam menerima pembelajaran sering kali mereka lebih suka bermain game selama pembelajaran. Sehingga siswa kurang konsentrasi dan tidak mampu memahami materi yang diajarkan (Harliawan et al., 2014).

Proses belajar mengajar yang disukai siswa mampu meningkatkan minat dan motivasi belajar yang nantinya akan meningkatkan hasil belajar siswa (Rosyidah, 2016). Hamalik dalam (Faelasofi, 2015) menyatakan bahwa ika seseorang telah melalui proses belajar maka hasil belajarnya terjadilah perubahan tingkah laku pada orang itu, misalnya dari yang tidak tahu menjadi tahu, dari yang tidah paham menjadi paham. Menurut Dalyono dalam (Muthoharoh, 2017) bahwa belajara adalah suatu kegiatan yang dilakukan dengan tujuan merubah tingkah laku. Perilaku tersebut berkaitan dengan pengetahuan, keterampilan maupun sikap yang merupakan hasil dari proses berlatih, dan pengalaman.

Berdasarkan latar belakang tersebut diatas, maka rumusan masalah dalam penelitian ini adalah apakah ada pengaruh media pembelajran berbasis Augmneted Reality (AR) terhadap 
hasil belajar siswa dalam pembelajaran biologi kelas X SMA Negeri 1 Gowa?. Tujuan dari penelitian ini adalah mengetahui pengaruh media pembelajaran berbasis Augmented Reality (AR) terhadap hasil belajar siswa dalam pembelajaran biologi kelas X SMA Negeri 1 Gowa.

\section{Metode Penelitian}

Penelitian ini merupakan penelitian Quasy Experiment atau eksperimen semu dengan menggunakan desain penelitian Posttest Only Control Group Design (Sugiyono, 2014). Penelitian ini telah dilaksanakan pada bulan oktober 2019 pada kelas X MIA SMA Negeri 1 Gowa semester ganjil tahun ajaran 2019/2020. Pemilihan sampel dilakukan secara random sampling sehingga terpilihlah kelas X MIA 3 sebagai kelas eksperimen dengan jumlah siswa sebanyak 36 orang dan X MIA 4 sebagai kelas kontrol dengan jumlah siswa sebanyak 36 orang.

Prosedur kerja atau Langkah-langkah proses pelaksanan penelitian ini yaitu a) tahap observasi, dilakukan sebagai Langkah awal penelitian di SMA Negeri 1 Gowa, dan diperoleh informasi tentang bagaimana hasil belajar biologi siswa kelas $\mathrm{X}$, kemudian jumlah siswanya, proses pembelajaran, dan lain sebagainya. Informasi tersebut diperolah dari hasil wawancara dengan salah satu guru biologi di SMA Negeri 1Gowa; b) tahap perencanaan/ persiapan, tahap ini merupakan tahap dalam memulai suatu kegiatan sebelum melangsungkan penelitian di lapangan untuk mengumpulkan data. Dimana peneliti terlebih dahulu menyiapkan RPP, silabus, media, dan perangkan pembelajaran lainnya yang dibutuhkan, serta mengurus surat izin untuk melakukan penelitian kepada pihak-pihak yang bersangkutan; c) tahap pelaksanaan, dilaksanakan berdasarkan pada RPP yang telah disusun dan dalam penelitian ini dilaksanakan selama 4 kali pertemuan. 3 kali untuk pertemuan memberikan materi ajar dan 1 kali pertemuan untuk posttest; d. tahap evaluasi, evaluasi dilakukan pada penelitian ini dengan melaksanakan tes akhir pertemuan atau posttest untuk mengetahuia hasil belajar siswa kelas X SMA Negeri 1 Gowa.

Adapun proses pengumpulan data dalam penelitian ini yaitu dengan pemberian posttest. Posttest dilakukan setelah pelajaran atau pemberian materi telah selesai. Soal tes sesuai dengan tingkat kognitif siswa dengan jumlah soal sebanyak 20 nomor dalam bentuk soal pilihan ganda. Data hasil tes hasil belajar kemudian dianalisis secara analisis statistik deskriptif dan inferensial.

\section{Hasil dan Pembahasan}

Penelitian eksperimen ini telah dilaksanakan pada SMA Negeri 1 Gowa pada semester ganjil tahuna ajaran 2019-2020 dengan populasi penelitian adalah seluruh siswa kelas X yaitu 
mulai X MIA 1 - X MIA 7. Penelitian eskperimen semu ini dilakukan untuk mengetahui ada tidaknya pengaruh media pembelajaran berbasis Augmented Reality (AR) terhadap hasil belajar biologi siswa kelas X MIA SMA Negeri 1 Gowa. Sampel dalam penelitian ini adalah kelas X MIA 3 sebagai kelas eksperimen sebanyak 36 orang siswa dan kelas X MIA 4 sebagai kelas kontrol sebanyak 36 orang siswa. Peneliti memberikan perlakuan (treatment) kepada kelas eksperimen dengan penggunaan media berbasis Augmented reality pada kelas X MIA 3, sedangkan pada kelas X MIA 4 menggunakan media dari guru mata pelajaran biologi di sekolah.

Posttest merupakan tes yang diberikan kepada siswa untuk memperoleh data hasil penelitian baik pada kelas eksperimen maupun kelas kontrol dengan tujuan untuk mengetahui kemampuan siswa setelah diberikan perlakukan yang berbeda. Data hasil belajar ini diperoleh dari tes tertulis berbentuk pilihan ganda sebanyak 20 nomor soal dengan materi virus. Kemudian data hasil belajar dianalisis menggunakan statistik deskriptif dan analisis statistic inferensial.

Berikut ini disajikan hasil analisis deskriptif hasil belajar siswa pada saat posttest kelas eksperimen (X MIA 3) dan kelas kontrol (X MIA 4) pada Tabel 1 dibawah ini.

Tabel 1. Hasil Analisis Deskriptif Hasil Belajar Posttest Kelas Eksperimen dan Kontrol

\begin{tabular}{ccc}
\hline Statistik & $\begin{array}{c}\text { Nilai Posttest } \\
\text { Ekperimen }\end{array}$ & $\begin{array}{c}\text { Nilai Posttest } \\
\text { Kontrol }\end{array}$ \\
\hline Jumlah Sampel & 36 & 36 \\
Nilai Ideal & 100 & 100 \\
Nilai Maksimum & 95 & 95 \\
Nilai Minimum & 65 & 50 \\
Niali Rata-Rata & 80 & 73 \\
\hline
\end{tabular}

Berdasarkan Tabel 1 diatas, menunjukkan bahwa nilai dari posttest diperoleh skor maksimum sebanyak 95, skor minimum 65, dan skor rata-rata 80. Apabila nila hasil belajar posttest kelas eksperimen dan kontrol dikelompokkan kedalam kelas interval skor, maka diperoleh distribusi frekuensi dan persentase hasil belajar seperti diperlihatkan pada Tabel 2 berikut:

Tabel 2. Distribusi Frekuensi dan Persentase Nilai Hasil Belajar Posttest Kelas Eksperimen dan Kontrol.

\begin{tabular}{ccccccc}
\hline \multirow{2}{*}{ No } & \multirow{2}{*}{ Interval } & \multirow{2}{*}{ Kategori } & \multicolumn{2}{c}{ Frekuensi } & \multicolumn{2}{c}{ Persentase (\%) } \\
\cline { 3 - 6 } & & & Eksperimen & Kontrol & Eskperimen & Kontrol \\
\hline 1. & $93-100$ & Sangat Baik & 1 & 1 & 2,8 & 2,8 \\
\hline
\end{tabular}




\begin{tabular}{ccccccc}
\hline \multirow{2}{*}{ No } & \multirow{2}{*}{ Interval } & \multirow{2}{*}{ Kategori } & \multicolumn{2}{c}{ Frekuensi } & \multicolumn{2}{c}{ Persentase (\%) } \\
\cline { 4 - 7 } & & Baik & 12 & 6 & 33,3 & 16,7 \\
\hline 2. & $84-92$ & & 18 & 10 & 50 & 27,8 \\
3. & $75-83$ & Cukup & 5 & 19 & 13,9 & 52,7 \\
4. & $<75$ & Kurang & 36 & 36 & 100 & 100 \\
& & Jumlah & 36 & Kontrol & Eskperimen & Kontrol \\
& & & & & &
\end{tabular}

Jika data tes hasil belajar Posttest kelas eksperimen dan kelas kontrol setelah diterapkan media pembelajaran dikategorikan berdasarkan indikator Kriteria Ketuntasan Minimal (KKM) hasil belajar siswa dapat dilihat pada Tabel 3 berikut.

Tabel 3. Kategori Ketuntasan Hasil Belajar Posttest kelas Eksperimen dan Kontrol

\begin{tabular}{cccccc}
\hline \multirow{2}{*}{ Interval Nilai } & \multirow{2}{*}{ Kategori } & \multicolumn{2}{c}{ Frekuensi } & \multicolumn{2}{c}{ Persentase (\%) } \\
\cline { 3 - 6 } & & Eksperimen & Kontrol & Eksperimen & Kontrol \\
\hline $75-100$ & Tuntas & 31 & 7 & 86,1 & 7,2 \\
$0-74$ & Tidak Tuntas & 5 & 9 & 13,9 & 2,8
\end{tabular}

Analisis statistik inferensial pada penelitian ini, dilakukan beberapa pengujian seperti normalitas, homogenitas, dan hipotesis. Ketiga uji tersebut dilakukan dengan menggunakan program aplikasi SPSS Ver.24. Hasil dari pengujian tersebut dapat dilihat pada Tabel 4 dibawah ini.

Tabel 4. Hasil Analisis Statistik Inferensial

\begin{tabular}{ccc}
\hline $\begin{array}{c}\text { Analisis Statistik } \\
\text { Inferensial }\end{array}$ & Teknik Pengujian & Signifikansi \\
\hline Uji Normalitas & Kolmogorov-Smirnov & $\begin{array}{l}\text { Posttest } \text { eksperimen }=0,067 \\
\text { Posttest } \text { kontrol }=0,083\end{array}$ \\
Uji Homogenitas & Homogeneity of Variance & 0,083 \\
& Independent Samples & \\
Uji Hipotesis & Test & 0,001 \\
\hline
\end{tabular}

Berdasarkan Tabel 4 diatas, hasil dari uji normalitas data hasil belajar dengan menggunakan analisis Kolmogorov-Smirnov menunjukkan bahwa nilai posttest kelas eksperimen dan kelas kontrol berdistribusi normal, dengan nilai sig 0,067 yang lebih besar dari nilai $\alpha=0,05$. Sesuai dengan ketentuan dari uji normalitas jika nilai signifikan lebih besar dari 0,05 maka data berdistribusi normal. 
Hasil uji homogenitas menggunakan Teknik pengujian Homogenity of Variance menunjukkan bahwa data penelitian ini homogen, dengan nilai Sig 0,038 $>0,05$ maka dinyatakan data homogen.

Hasil uji hipotesis menggunkan analisis Independent Sample T Test, menunjukkan nilai signifikansi dari data penelitian yaitu 0,001 dimana nilai sig $<0,05$. Maka dapat disimpulkan bahwa ada pengaruh media pembelajaran berbasis Augmented Reality (AR) terhadap hasil belajar. Sesuai dengan pengambilan keputusan Teknik pengujian Independent Sample T Test, jika nilai sig $\leq 0,05$ maka $\mathrm{H}_{0}$ ditolak dan $\mathrm{H}_{1}$ diterima.

Data hasil penelitian yang telah dilakukan di kelas X SMA Negeri 1 Gowa, menunjukkan bahwa ada pengaruh yang signifikan terhadap hasil belajar siswa sehingga terlihat perbedaan nilai hasil belajar mereka pada kelas eksperimen yang menggunakan media pembelajaran berbasis Augmented Reality (AR) dengan kelas kontrol yang menggunakan media pembelejaran yang biasa digunakan oleh guru yang mengajar dikelas tersebut. Analisis deskriptif menunjukkan perbandingan dengan nilai rata-rata pada kelas kontrol yaitu 73 lebih rendah dibandingkan dengan nilai rata-rata pada kelas eksperimen yaitu 80. Sedangkan [ada pengujian hipotesis dengan menggunakan uji Independent Sample $\mathrm{T}$ Test diperoleh nilai signifikansi 0,001 dimana nilai signifikansi tersebut lebih kecil dari nilai alfa $=0,05(0,001<$ 0,05). Dengan demikian, $\mathrm{H}_{0}$ ditolak dan $\mathrm{H}_{1}$ diterima maka dapat disimpulkan bahwa ada pengaruh media pembelajaran berbasis Augmented Reality (AR) terhadap hasil belajar siswa.

Berdasarkan analisis tersebut dimana pembelajaran menggunakan media pembelajaran berbasis Augmented Reality (AR) memberikan pengaruh terhadap hasil belajar siswa. Hal ini dikarenakan, melalui media pembelajaran berbasis AR dapat memvisualisasikan konsep abstrak untuk dipahami dan struktur suatu model objek, serta memberikan tampilan yang lebih menarik pada fitur-fitur aplikasi. Memungkinkan media pembelajaran ini sebagai media yang lebih efektif sesuai dengan tujuan dari media pembelajaran yang dapat meningkatkan semangat belajar dan hasil belajar siswa. Keberhasilan dari penerapan media pembelajaran berbasis Augmented Reality (AR) ini juga dapat dilihat dari aktivitas siswa. Hal ini dikarenakan selama proses pembelajaran berlangsung Sebagian besar siswa mampu berpartisipasi dengan baik.

Perolehan hasil belajar dari penelitian ini mencapai nilai kriteria ketuntasan miniman (KKM). Hal tersebut tercapai melalui penerapan perlakukan dengan menggunakan media pembelajaran berbasis Augmented Reality. Media ini sangat bermanfaat bagi siswa karena membuat siswa lebih aktif dalam proses pembelajaran serta siswa dapat dengan mudah memahami materi pembelajaran yang diberikan oleh peneliti/ guru. Keaktifan siswa dalam proses pembelajaran dapat membantu meningkatkan hasi belajar (Pulungan, 2017). Hasil 
penelitian ini sesuai dengan teori yang dikemukakan oleh (Halidi et al., 2015) menyatakan bahwa media pembelajaran Augmented Reality (AR) dapat diterima dengan oleh siswa, serta dinilai mampu untuk digunakan dengan baik dalam pembelajaran di kelas. Memiliki keberlanjutan yang baik untuk digunakan dalam jangka waktu ke depan sesuai dengan penggunaan dalam lingkup pembelajaran. Pemanfaatan media pembelajaran berbasis Augmented reality juga menjadi kesenangan tersendiri bagi siswa karena menjadikan mereka lebih aktif dalam proses belajar mengajar jika dalam pembelajaran guru menggunakan media pembelajaran AR, karena dapat meningkatkan hasil belajar siswa.

\section{Kesimpulan}

Berdasarkan hasil penelitian dan pembahasan maka dapat disimpulkn bahwa ada pengaruh penggunaan media pembelajaran berbasis Augmented Reality (AR) terhadap hasil belajar biologi siswa kelas X SMA Negeri 1 Gowa. hasil uji hipotesis didapatkan data yaitu sig. $0,001<0,05$, maka $\mathrm{H}_{0}$ ditolak dan $\mathrm{H}_{1}$ diterima. Diharapkan kepada peneliti yang selanjutnya untuk dapat mengembangkan media pembelajaran berbasis Augmented Reality (AR) sehingga menghasilkan produk.

\section{DAFTAR PUSTAKA}

Aqib, Z. (2013). Model-Model, Media dan Strategi Pembelajaran Kontekstual (Inovatif). Bandung: CV Yrama Widya.

Faelasofi, R. (2015). Penggunaan Media Pembelajaran Microsoft Office Powerpoint Pada Pokok Bahasan Peluang. Jurnal E-DuMath, 1(1), 17-29. https://ejournal.stkipmpringsewu-lpg.ac.id/index.php/edumath/article/download/79/30.

Halidi, H. M., Husain, S., \& Saehana, S. (2015). Pengaruh Media Pembelajaran Berbasis Augmented Reality Terhadap Motivasi Dan Hasil Belajar Ipa Siswa Kelas V Sdn Model Terpadu Madani Palu. Jurnal Mitra Sains, 3(1), 53-60. http://www.jurnal.unsyiah.ac.id/JIPI/article/download/9691/7671.

Harliawan, H., Tripalupi, L. E., \& Indrayani, L. (2014). Penggunaan Media Pembelajaran Berbasis TIK Untuk Meningkatkan Hasil Belajar IPS Kelas VIII J SMP Negeri 5 Singaraja. Jurnal Pendidikan Ekonomi Undiksha, 4(1), 1-11. https://doi.org/http://dx.doi.org/10.23887/jjpe.v4i1.2024.

Mehram. (2017). Upaya Meningkatkan Kemampuan Guru Dalam Merancang Eksperimen Virtual Kimia Sederhana Dengan Microsoft Power Point Melalui Workshop Mgmp Kimia SMA Binaan Di Kabupaten Pidie Provinsi Aceh. Jurnal Serambi Ilmu, 18(1-10). https://doi.org/https://doi.org/10.32672/si.v18i1.1033.

Muslih. (2016). Pemanfaatan Media Pembelajaran Berbasis Augmented Reality pada Lembaga 
Pendidikan Non-Formal TPQ. UIN Walisongo Journals, 16(2), 215-232. https://doi.org/https://doi.org/10.21580/dms.2016.162.1090.

Muthoharoh, N. B. (2017). Pengaruh Model Pembelajaran Kooperatif "Think Pair Share (Tps)" Terhadap Hasil Belajar Bahasa Inggris. Jurnal SAP, 2(1), 33-42. https://doi.org/http://dx.doi.org/10.30998/sap.v2i1.1509.

Pulungan, S. (2017). Pemanfaatan Augmented Reality (AR) Dalam Pembelajaran PAI. Jurnal Sistem Informasi, $1(1)$, 19-24.

http://jurnal.uinsu.ac.id/index.php/query/article/download/636/460.

Riyana, C. (2012). Media Pembelajaran. Jakarata; Direktorat Jenderal Pendidikan Islam Kementerian Agama Republik Indonesia.

Rosyidah, U. (2016). Pengaruh Model Pembelajaran Kooperatif Tipe Jigsaw Terhadap Hasil Belajar Matematika SiswaKelas Viii Smp Negeri 6 Metro. Jurnal SAP, 1(1), 115-124. https://doi.org/http://dx.doi.org/10.30998/sap.v1i2.1018.

Sugiyono. (2014). Metode Penelitian Kuantitatif Kualitatif Dan R\&D. Bandung: Alfabeta. 